\title{
erich weede: a nonconformist conflict researcher ${ }^{1}$
}

\section{gerald schneider}

Department of Politics and Management, University of Konstanz, D-78457 Konstanz, Germany

E-mail: gerald.schneider@uni-konstanz.de

doi:10.1057/palgrave.eps.2210037

\begin{abstract}
The second winner of the Richardson Lifetime Achievement Award (in 2004) was Professor Erich Weede from the University of Bonn, Germany. The prize, which is sponsored by two sections of the European Consortium of Political Research (ECPR), goes tri-annually to a political scientist who made major contributions to peace and conflict research in the tradition of Lewis Frye Richardson (1881-1953), a British meteorologist and pioneering scientific analyst of international war. This essay summarises some of the most important insights of the present award holder.
\end{abstract}

Keywords peace research; rent seeking; award; Lewis Frye Richardson

$\mathrm{T}$

he first time I encountered Erich Weede was during a lecture he gave at my Alma Mater. 'What an ideologue!' was my graduate student reaction to his speech on rent seeking and the advantages of free markets over political arrangements. It was around the end of the Cold War and thus in a period where Hayekian praise of capitalist self-regulation was still daring in some intellectual circles.

Although Weede did not manage to dismantle planned socialism all by himself, history has shown that many of the firm beliefs he advanced during the EastWest confrontation were correct. Yet, at that time, most colleagues still resisted this bluntness and preferred the dogma that the 1968 'revolution' had established in many political science departments around the world. As I only noticed later, in particular while reading Weede's masterful Weberian treatise Wirtschaft, Staat und Gesellschaft (Weede, 1990), he was not the opinionated essayist I originally thought when I saw him performing. (Almost) all of his convictions were based on his own empirical research or on his broad reading of the rigorous literature published in two fields, international relations and political economy. The Lewis Frye Richardson Lifetime Achievement Award he received at the meeting of the European Consortium for Political Research (ECPR) Standing Group on International Relations at The Hague in September 2004 provides a good occasion for summarising the broad contributions of this intellectual leader. ${ }^{2}$ 


\section{THE POPPERIAN BACKGROUND}

Weede's approach to political science is Popperian in the sense that he lives up to the ambition of only accepting arguments that have been systematically confronted with empirical evidence. Yet, this insistence on falsification does not turn him into a bare-foot empiricist. On the contrary, Weede deduces all these hypotheses from influential theories that have a lasting long-term influence on academic debates and are not as easily forgotten as some trendy conceptual 'innovations' that no one can recall after two or three conferences. Although Weede is not a modeller, his verbal and oral theorising is as crisp and clear as if he had developed these theories based on mathematical reasoning. The introduction to Wirtschaft, Staat und Gesellschaft briefly summarises Weede's (1990: 1, own translation) scientific ideal: 'What we may wish for are parsimonious and general theories that are rich in content and testable'. He acknowledged, however, that we are far away from a general theory of economic development and democracy and might, therefore, pragmatically opt to integrate the 'fragments' that complete each other:

'...partial failure is the "normal" fate of a social scientist given the current state of the social sciences' (idem, own translation).

Weede's biography partly explains how this 'critical rationalist', to use a Popperian attribute, came to make a lasting influence on the scientific study of international relations. The award holder is one of the many scholars who worked under the guidance of Rudolf Wildenmann, one of the 'fathers' of the ECPR and a foremost behaviouralist of the 1960s and 1970s at the University of Mannheim. Erich Weede, who was born in Hildesheim in 1942, had first studied psychology in Hamburg before he took up studies in sociology and political science. He concluded his disser- tation with an empirical study on the behaviour of states in 1970 (Weede, 1971) and published his habilitation (the 'second' doctorate that was then mandatory - and still partly is - for pursuing an academic career at German universities), his first opus magnum, five years later (Weede, 1975). This massive monograph on the causes of war evinces the influence of some of the pioneers in the quantitative analysis of war, most notably Lewis Frye Richardson, Harold Guetzkow, J. David Singer and Rudoph J. Rummel. Weede spent some time at the end of the 1960s at Northwestern University with Guetzkow who had pioneered the usage of computer simulation in international relations theory.

Weede also followed an ICPSR methods course in Ann Arbor where Singer in the early 1960s had started the 'Correlates of War' project with the most comprehensive list of armed conflict. He followed in the footsteps of these pioneers and brought statistical methods to the analysis of international interactions. A particular proof of this dedication to systematic tests is his classic treatise on Asian dyads in which he demonstrated that only massive 'preponderance' and thus a clear power advantage is a major pacifying force (Weede, 1976). This work qualified the conjecture of Organski (1965) that power imbalances generally reduce the likelihood of armed conflict. Weede embedded his analysis in a nonformal deterrence framework, a topic to which he has made several contributions over the years. One of the strongest innovations of the 1976 Journal of Conflict Resolution article on power preponderance was its attempt to gauge the impact of power distribution at the level of pairs of states instead at the systemic level of interaction, as was then still the fashion. To use pairs of states - or so-called dyads - as the unit of analysis has become the norm in quantitative studies of interstate war over the years and has particularly 
influenced how studies in another cottage industry - studies on the so-called 'democratic peace' - are executed.

\section{'DEMOCRATIC PEACE'}

The French Prime Minister G. Clemenceau said once that democracy would be a lot easier if governments were not forced to win elections. A political science paraphrase of this could be that a researcher's life would be more comfortable if he/she did not have to regularly live up to peer scrutiny. As Erich Weede has not given up the ambition of publishing in respected places and has continuously sent his work to top-ranked journals, he has remained unafraid of exposing his ideas to the challenge of critical (and envious) colleagues. In his generation he is certainly one of the scholars with the highest number of articles indexed in prestigious electronic libraries such as JSTOR or ISI Web of Science. An anecdote that has gone around in the European conflict research group illustrates this. Weede has remarked on several occasions that his target was a $50 \%$ personal rejection rate in academic journals. If he fell below this level, he had not been sufficiently ambitious in where he submitted his articles. ${ }^{3}$

The personal learning that participation in a major academic debate brings about can be illustrated by Weede's contribution to the debate on the 'democratic peace', the proposition that democracies do not fight each other. Some of his publications of the 1980s only took 'realist' explanatory factors such as superpower deterrence into account (e.g. Weede, 1983). In his first international contribution to the debate, Weede (1984: 660) calculated the bivariate correlations between democracy and war involvement and concluded: 'Although there are periods of observation, where libertarianism or democratic performance is negatively correlated with war involvement, such periods of observation have been short in duration'. He acknowledged, however, eight years later, that the conclusion he drew from these calculations are only partly correct as they invalidated the monadic ('democracies are more peaceful than autocracies') and not the dyadic ('democratic pairs of states are more peaceful than autocratic pairs of states') vrsion of the democratic peace (Weede, 1992). ${ }^{4}$

Weede's (1995) later work on the topic masterfully links different strands of liberal thinking, most notably commercial liberalism ('the more states trade with each other, the less likely a conflict becomes') and the democratic peace thesis. Yet, his synthesis also considers realist explanations of war and peace and, most importantly, the economic interests of protectionist lobbies. He particularly warned in this vein against the hopes of some liberalist thinkers that trade is an unambiguous source of peace. Weede saw the main limitation of what Rosecrance (1986) has called the 'trading state' in the domestic power of special interests. In his view, 'Most special interest groups are not concerned with international security issues but with domestic advantage and redistribution, i.e. with rent-seeking. Nevertheless, they may effectively undermine international security' (Weede, 1995: 529).

This skeptical researcher has even become over the years, probably against his initial personal predisposition, an ardent defender of the democratic peace hypothesis. This is revealed in his criticism of a series of articles by Snyder and Mansfield (e.g. 1995), who argued that democratising pairs of states face a higher risk of conflict than dyads in which no international reform process takes place. Weede particularly points out in his rebuttal that these authors failed to show that young democracies are necessarily more incoherent and inconsistent than established political regimes: 'In science, attacks are fruitful. I am an adherent of 
the peace-by-democracy view who still retains some doubts. I can imagine changing my views on democracy and peace again. But Mansfield and Snyder's study offers too little compelling evidence or theorising' (Weede, 1999: 183).

\section{REBELLION, REVOLUTION AND VIOLENCE}

Erich Weede has also, in joint work with Edward N. Muller, contributed to the literature on political violence within nation states. They develop a 'rational action' approach of political violence, which essentially boils down to calculating the opportunity costs of rebellion. As the statistical evidence in the first paper shows, the level of domestic political violence is high when government repression is at an intermediate level. High economic growth, by contrast, reduces the incidence of civil strife (Weede and Muller, 1990). Interestingly, this rational actor approach dominates current research on civil war, as revealed by the influential papers of Collier and Hoeffler (2004) and Fearon and Laitin (2003). These authors develop an argument that is very close to what Weede and Muller have written. Collier and Hoeffler, in particular, share Weede's scepticism towards the 'grievance' approach and therefore, the expectation that political violence is a positive function of political repression. The only major separation between current research on domestic political violence and the papers that Muller and Weede wrote together ten years ago is the level of formalisation of the underlying expected utility argument. Current research in this field is largely based on mathematical models that explain the level of conflict through the interaction of government and rebel forces while Weede and Muller offer a largely empirical approach and refrain from developing an explicit model. ${ }^{5}$ In their first paper on the topic, Muller and
Weede (1990: 628, italics in the original) defended their position forcefully and wrote: 'Although we recognise that many important issues in the rational action perspective cannot be dealt with effectively using available data, we believe that some tests, even if they are preliminary, are better than none'.

\section{CONTRIBUTIONS TO THE POLITICAL ECONOMY LITERATURE}

It would not be accurate to reduce Erich Weede's contribution just to the insights that he contributed to the peace and conflict literature. He also made some lasting contributions to the political economy literature; summaries of these findings can be found in two monographs (Weede, 1990, 1996), which also offer a linkage between the political economy literature and international relations theory. The first series of IPE papers by Weede exhibits a rather combative trait in his character. He rejected, partly in collaboration with Horst Tiefenbach, dependencia interpretations of income inequality (e.g. Weede, 1980). The joint work on the determinants of income inequality illustrates how solid research can refute influential thesis and thus contribute to the accumulation of knowledge. Weede and Tiefenbach $(1981 a, b)$ examined three strands of dependence theory, showing that the research published until then often suffered under the misspecification of the statistical models. The debate with the dependency theorists on the role of investment on inequality culminates in the Lakatosian verdict that the 'ad hoc revisions' of one competing colleague 'merely serve the purpose of making his central proposition immune to empirical criticism' (Weede and Tiefenbach, 1981b: 292).

A second line of research in the field of international political economy to which Weede contributed greatly is the empiri- 
cal study of the causes and consequences of rent seeking. Weede particularly tested the Olsonian hypotheses that distributional coalitions are a major cause of economic decline. He advanced this belief at a time when most academics still believed that German corporatism and other forms of 'economic governance' are more successful than less interventionist forms of interest intermediation. Weede (1986b), for instance, examined the role of transfer payments and increasing government activity in economic growth. His results are in considerable contrast to the optimistic globalisation literature of the mid-1990s, which maintained that governments are still able to compensate the losers of globalisation. Weede (1986b: 217) showed, by contrast, that government interventionism is likely to backfire, and that old democracies are more at risk than younger ones: '...the expanding welfare state seems to contribute fairly strongly and about as much as aging democracies to unemployment... It is conceivable and desirable that one tries to achieve some reduction in public sector size, some steps back on the 'road to serfdom', in order to promote growth and, possibly and hopefully, even employment'.

Even in the light of these findings and qualifications it would be very wrong to connect Weede with conservativism. He is rather one of these maverick libertarians who might find an intellectual place, if they ever sought one, in a party that advocates both civil liberties and economic freedom. As we sadly know, there is no such animal around at the moment, at least not in Germany and other Western European states. An episode from the 1990s illustrates that a true libertarian does often not live up to the expectations of a complacent audience. He was once invited to deliver a speech to the rightwing and anti-integrationist Campaign for an Independent and Neutral Switzerland (AUNS). The delegates expected that Weede would confirm their anti-immigra- tion and protectionist biases. According to a newspaper report, the contrary was the case. Weede criticised the European Union, but also told the shocked listeners how good competition and immigration is for development (Neue Zürcher Zeitung, May 9 1998).

\section{A RESEARCHER IN EXILE}

Weede has worked as a professor of political science from 1979 to 1997 in Cologne and since then in neighbouring Bonn. One of the oddities of his career is that both these positions, the first one at the associate, and the second at the fullprofessor level, were in sociology departments. Weede's refusal to build his own intellectual empire - or 'school' as these networks of academic despondence are often euphemistically called - probably contributed to this professional isolation. Yet, the 'exile' was probably not only due to his intellectual independence and sovereignty. It is probably not much of a compliment to the peace research community that this most prolific and internationally influential German conflict researcher of his age cohort was a 'researcher in exile' for almost his entire professional career and never worked in a political science department as full professor. Yet, this lack of formal recognition did not silence Weede. He is still one of the most entertaining, incisive and provocative presenters the international relations community has known over the past few decades. Weede remained, more importantly, over all these years, a regular contributor to major journals and still publishes original books and articles, among them most recently his libertarian treatise Mensch, Markt und Staat (Weede 2003) and an insightful treatise on political violence (Weede 2004). These signs of a continuous dedication to rigorous and politically relevant research alone are an exemplary proof that the Richardson Lifetime Achievement Award is fully deserved. 


\section{Notes}

1 I thank Nils Petter Gleditsch, Thomas Plümper and Erich Weede for comments on this tribute.

2 The award is a joint initiative of two Standing Groups of the ECPR, the one on Analytical Politics and Public Choice and the one on International Relations. The award committee consisted of Wolf-Dieter Eberwein (Grenoble/Berlin), Nils Petter Gleditsch (Oslo/Trondheim), Hugh Ward (Essex) and the author. Erich Weede is the second award winner; the first award went to the late Michael Nicholson (Sussex). An obituary of the first award holder by Amartya Sen was published in the first issue of EPS; see http:// www.essex.ac.uk/ECPR/publications/eps/onlineissues/autumn2001/obituary.htm.

3 Nils Petter Gleditsch told this story during the workshop that was held in honour of Erich Weede during the The Hague meeting. Ekkehart Zimmermann confirmed having heard something similar. Erich Weede himself had forgotten that he made this remark, but conceded that he might have well have said it.

4 In the meantime, even the monadic version found some empirical support (Benoit, 1996) and theoretical justification (Schultz, 1998) in the literature.

5 The collaborative work between Erich Weede and Edward Muller did not result in a monograph because of the untimely death of Muller in 1995.

\section{References}

Benoit, K. (1996) 'Democracies Really are More Pacific (In General): Re-examining Regime Type and War Involvement', Journal of Conflict Resolution 40, 636-657.

Collier, P. and Hoeffler, A. (2004) 'Greed and Grievance in Civil War', Oxford Economic Papers 56, 563-595.

Fearon, J. and Laitin, D. (2003) 'Ethnicity, Insurgency, and Civil War', American Political Science Review 97, 75-90.

Organski, A.F.K. (1965) World Politics, New York: Knopf.

Rosecrance, R. (1986) The Rise of the Trading State. Commerce and Conquest in the Modern World, New York: Basic Books.

Schultz, K. (1998) 'Domestic Opposition and Signaling in International Crises', American Political Science Review 92, 829-844.

Weede, E. (1971) 'Charakteristika von Nationen als Erklärungsgrundlage für das internationale Konfliktverhalten', Sozialwissenschaftliches Jahrbuch für Politik, Band 2, pp. 327-401.

Weede, E. (1975) Weltpolitik und Kriegsursachen im zwanzigsten Jahrhundert: Eine quantitativempirische Studie, München: Oldenbourg.

Weede, E. (1976) 'Overwhelming Preponderance as a Pacifying Condition Among Contiguous Asian Dyads, 1950-1969', Journal of Conflict Resolution 20, 395-411.

Weede, E. (1980) 'Beyond Misspecification in Sociological Analyses of Income Inequality', American Sociological Review 45, 497-501.

Weede, E. (1983) 'Extended Deterrence by Superpower Alliance', Journal of Conflict Resolution 27(2): 231-253 (see also 27(4): 739).

Weede, E. (1984) 'Democracy and War Involvement', Journal of Conflict Resolution 28, 649-664.

Weede, E. (1986a) 'Catch-up, Distributional Coalitions and Government as Determinants of Economic Growth or Decline in Industrialized Democracies', British Journal of Sociology 37, 194-220.

Weede, E. (1986b) 'Rent Seeking, Military Participation, and Economic Performance in LDCs', Journal of Conflict Resolution 30, 291-314.

Weede, E. (1990) Wirtschaft, Staat und Gesellschaft, Tübingen: Mohr.

Weede, E. (1992) 'Some Simple Calculations on Democracy and War Involvement', Journal of Peace Research 29, 377-383.

Weede, E. (1995) 'Economic Policy and International Security: Rent-Seeking, Free Trade and Democratic Peace', European Journal of International Relations 1, 519-537.

Weede, E. (1996) Economic Development, Social Order and World Politics, Boulder, CO: Lynne Rienner. Weede, E. (1999) 'Democratization and the Danger of War (in Correspondence)', International Security 20(4): 180-183.

Weede, E. (2003) Mensch, Markt und Staat: Plädoyer für eine Wirtschaftsordnung für unvollkommene Menschen, Stuttgart: Lucius et Lucius.

Weede, E. (2004) 'On Political Violence and its Avoidance', Acta Politica 39, 152-178.

Weede, E. and Muller, Edward N. (1990) 'Cross-National Variation in Political Violence', Journal of Conflict Resolution 34, 624-651. 
Weede, E. and Muller, Edward N. (1998) 'Rebellion, Violence and Revolution: A Rational Choice Perspective', Journal of Peace Research 35, 43-59.

Weede, E. and Tiefenbach, H. (1981a) 'Some Recent Explanations of Income Inequality: An Evaluation and Critique', International Studies Quarterly 25, 255-282.

Weede, E. and Tiefenbach, E. (1981b) 'Some Recent Explanations of Income Inequality: Rejoinder', International Studies Quarterly 25, 289-293.

\section{About the Author}

Gerald Schneider has been Professor of Political Science at the University of Konstanz, where he holds the International Relations Chair, since 1997. He is also Executive Editor of the journal European Union Politics. His main areas of research are decision making in the EU and the economic causes of armed conflict. His recent papers have been published in Acta Politica, European Journal of International Relations, Journal of Conflict Resolution, Millennium, Political Studies and Rivista di Politica Economica, among others. 